\title{
THE LAW ON PUBLIC PROCUREMENT - THE SCOPE AND THE PROCEDURE OF ITS APPLICATION IN THE HEALTH CARE SYSTEM
}

\author{
Doctor of Economics Pulatov Kh. Dilshod, \\ Uzbekistan
}

DOI: https://doi.org/10.31435/rsglobal_ijite/31032019/6373

\begin{abstract}
This article is devoted to the ongoing reforms in the field of public procurement in the Republic of Uzbekistan, in particular the adoption of the law "On public procurement", highlights the main concepts of the Law. The system of procurement of goods and services by health care organizations was also studied, emerging problems in the procurement process and methods for their solution were studied. Developed scientific and practical suggestions and recommendations.
\end{abstract}

Government procurement, government procurement principles, government procurement process,

Government customers, corporate customers.

Citation: Pulatov Kh. Dilshod. (2019) The Law on Public Procurement - the Scope and the Procedure of Its Application in the Health Care System. International Journal of Innovative Technologies in Economy. 2(22). doi: 10.31435/rsglobal_ijite/31032019/6373

Copyright: (C) 2019 Pulatov Kh. Dilshod. This is an open-access article distributed under the terms of the Creative Commons Attribution License (CC BY). The use, distribution or reproduction in other forums is permitted, provided the original author(s) or licensor are credited and that the original publication in this journal is cited, in accordance with accepted academic practice. No use, distribution or reproduction is permitted which does not comply with these terms.

In accordance with the Decree of the President of the Republic of Uzbekistan dated October 05, 2016 No.UP-4848 "On additional measures to ensure the accelerated development of entrepreneurship, full protection of private property and qualitative improvement of the business climate",the Program of comprehensive measures to ensure the accelerated development of entrepreneurship, full protection of private property and qualitative improvement of the business climate in the Republic of Uzbekistanwas developed. According to paragraph 5 of this Program, the Ministry of Finance, the Ministry of Justice, the Ministry of Economy, the State Committee of the Republic of Uzbekistan for Assistance to Privatized Enterprises and Development of Competition, the Ministry for Development of Information Technologies and Communications of the Republic of Uzbekistan, the Council of Ministers of the Republic of Karakalpakstan, as well as khokimiyats of regions and Tashkent were instructed to develop a draft law "On public procurement" by the $2^{\text {nd }}$ quarter of 2017.

The Decree provided for the following:

- transparent and open mechanism of public procurement on a competitive basis, measures to prevent corruption in this area;

- wide access of small businesses and private entrepreneurship to public procurement;

- expansion of the range of subjects for which the use of public procurement system is mandatory with the inclusion of state enterprises, as well as commercial organizations with a state share of 50 percent or more;

- establishment of an independent and effective system and appeal procedures for public procurement participants; 
- further development of electronic procurement, the organization of a single database for statistical analysis of the results, the necessary parameters of procurement.

In pursuance of the Decree of the President of the Republic of Uzbekistan, the draft law "On public procurement" developed in due time after signing it by all Ministries, State Committees and Departments involved in the development of the draft law, as well as the legal expertise of the Ministry of Justice, was submitted to the Cabinet of Ministers of the Republic of Uzbekistan on May 30, 2017, and on August 21, 2017 was approved by the Board of the Cabinet of Ministers.

In the future, in accordance with paragraph 2 of clause 5 of the Resolution of the President of the Republic of Uzbekistan dated September 23, 2017 No.PP-3237 "On measures for the further introduction of modern forms and methods of public and corporate procurement of goods (works, services)",the National Project Management Agency under the President of the Republic of Uzbekistan together with the concerned Ministries and Departments was entrusted to submit in the prescribed manner the draft law of the Republic of Uzbekistan "On public procurement". The draft law was approved by the Senate of the Oliy Majlis on March 29, 2018 and signed by the President of the Republic of Uzbekistan on April 09, 2018.

The main purpose of the Law is to create a transparent and open mechanism for the implementation of public (corporate) procurement on a competitive basis, the adoption of measures to prevent corruption in this area; ensuring broad access of business entities to public (corporate) procurement; unification of all rules and regulations, which are established by more than 30 legal acts, in one document and regulation of relations in the field of public procurement.

The Law consists of 12 Chapters and 79 Articles. The main innovations are the following.

First, the basic principles of public procurement are defined:

- professionalism of the state customer;

- validity;

- rationality, efficiency and effectiveness of the use of financial resources;

- openness and transparency;

- competitiveness and objectivity;

- proportionality;

- unity and integrity of the public procurement system;

- inadmissibility of corruption.

The basic principles of public procurement shall be applied at all stages of the public procurement process (Article 4).

Secondly, in accordance with Article 14 of the Law, the National Project Management Agency under the President of the Republic of Uzbekistanwas determined as the authorized body in the field of public procurement.

Thirdly, five specific types of procurement procedures have been established:

- e-shop;

- auction to lower the starting price;

- competition;

- tender;

- Public procurement from a single supplier.

Fourth, the definition of the Procurement Commission in the implementation of public procurement and simplification of its composition;

Fifth, it provides for the establishment of a special Commission to consider disputes and complaints on all types of procurement in the field of public procurement.

The authorized body, that is, the National Project Management Agency under the President of the Republic of Uzbekistancarries out the state policy in the field of public procurement, approves the model documents, the procedure for choosing the method of public procurement and their procedure; determines the operator of a special information portal and the rules of its activities in relation to the organization and conduct of public procurement.

Special attention is paid to a special information portal. A special information portal is a website and a special electronic platform of the operator, ensures the implementation of government procurement, accommodation and access to view in electronic form declarations on public procurement information on the outcome of public procurement, the proposals of the participants of 
the procurement procedure and other information required by law, as well as conducting electronic public procurement.

To participate in electronic public procurement, the supplier shall register in the prescribed manner in a special information portal and post their proposals for public procurement announcements.

Participants of public procurement can become a state customer, the Procurement Commission, the operator of a special information portal, experts.

Now we will give a more complete definition to customers of public procurement.

State customer is a legal entity engaged in public procurement, and in accordance with Article 16 of the Law "On public procurement", is divided into two categories:

1)budget customers:

State bodies;

Budgetary institutions;

Recipients of budget funds allocated for the implementation of procurement procedures;

State trust funds;

2) corporate customers:

State enterprises;

legal entities with state participation in their authorized fund (authorized capital) in the amount of 50 percent or more;

legal entities in the authorized fund (authorized capital) of which 50 percent or more belongs to a legal entity with a state share of 50 percent or more.

In this article, we consider the procedure for public procurement only by budget customers.

Types of public procurement differ in specific features. First, it is the maximum cost of procurement and secondly, the form of implementation, that is, procurement procedures.

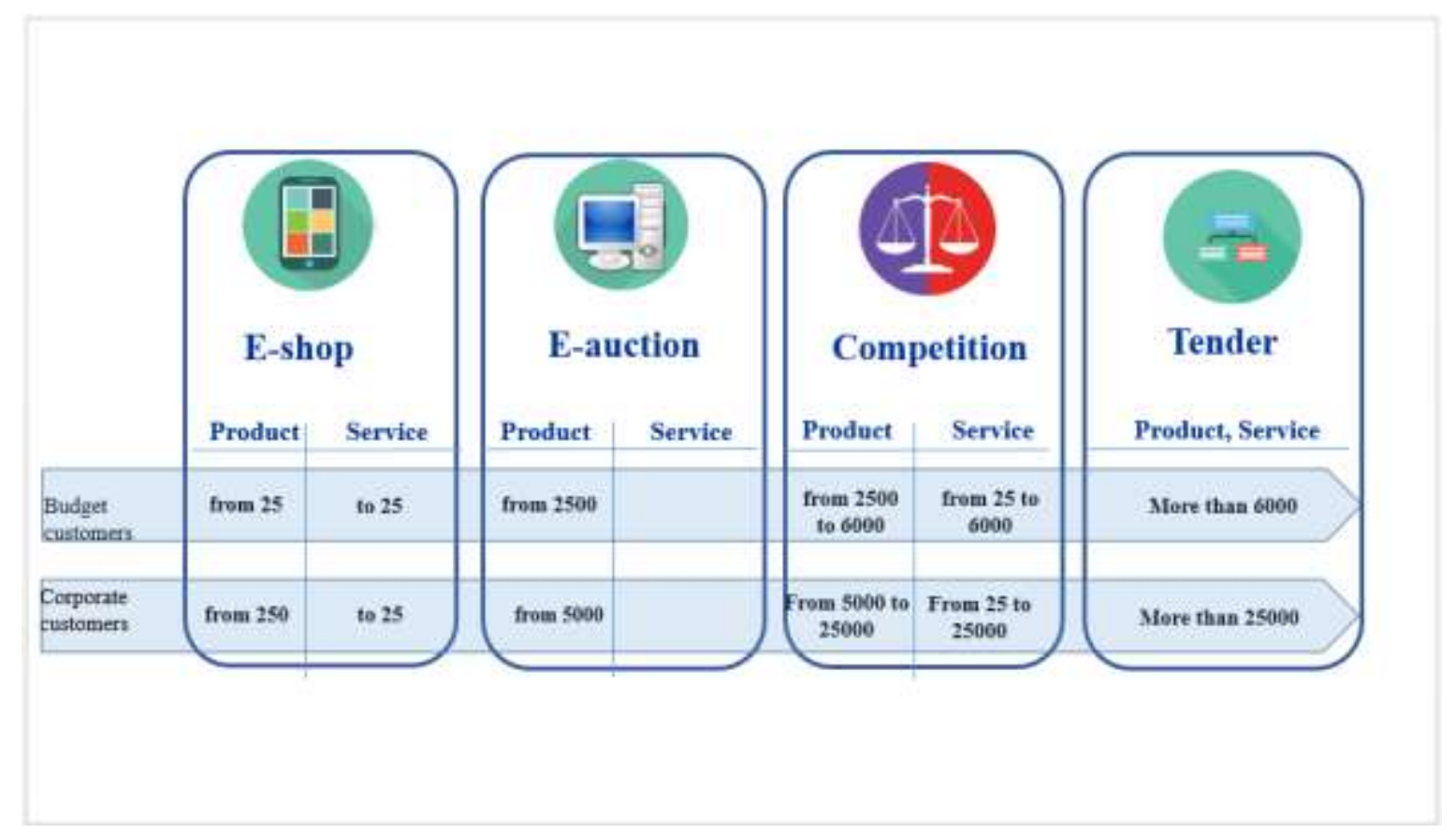

Fig. 1. Types of procurement and procedure for their implementation

Thus, public procurement can be carried out in the e-shop:

- simple consumer goods that do not have complex technical characteristics for an amount not exceeding two hundred and fifty minimum wages under one contract (for budget customers twenty-five minimum wages), but not more than the amount of two thousand five hundred minimum wages per year for one state customer; customer

- works, services for an amount not exceeding twenty-five minimum wages for one state

Participants have the right to submit their proposals within forty-eight hours from the date of sending a special information portal offers to participate in the request for prices. 
When selling goods through an e-auction, the cost of goods is less than five thousand minimum wages under one contract. For budget customers, public procurement in the auction shall not exceed two thousand five hundred minimum wages under one contract. The announcement of the competition is placed by the state customer on a special information portal at least ten days before the deadline for receiving proposals from participants.

Public procurement through competition is carried out in the case of simultaneous fulfillment of the following conditions:

For budget customers in public procurement at the competition:

the cost of goods shall be from two thousand five hundred minimum wages to six thousand minimum wages under one contract;

the cost of works and services shall be from twenty-five minimum wages to six thousand minimum wages under one contract.

The announcement of the competition is placed by the state customer on a special information portal not less than thirty days before the deadline for receiving proposals from the participants of the competition.

Public procurement through tender is carried out in case of simultaneous fulfillment of the following conditions:

the criteria for determining the winner are not only a monetary assessment, but a quantitative and qualitative assessment of the goods (works, services);

the cost of goods (works, services) is more than twenty-five thousand minimum wages under one contract.

For budget customers, public procurement in the tender shall amount to more than six thousand minimum wages under one contract.

The announcement of the tender is placed by the state customer on a special information portal not less than thirty and not more than forty-five days before the deadline for receiving proposals from bidders.

The e-public procurement system has the following advantages:

First, e-public procurement is carried out only with the use of an electronic digital signature. At the same time, the placement of announcements and the signing of contracts are carried out in electronic form.

Second, customers and suppliers pay the same amount of collateral to participate in e-bidding as security of supply.

Thirdly, in this system, the procurement process and payment terms have been significantly reduced.

And most importantly, entrepreneurs have wide opportunities to sell their products through the system of public procurement.

Placement of procurement announcements on a special information portal before the start of procurement is considered mandatory for all. This rule is established to increase the transparency of public procurement and the broad involvement of businesses.

According to the results of the competition (tender), the winner is not only the participant who submitted the offer with the lowest price, but also the one who submitted the best offer.

The last fifth type of procurement is Single suppliers, which can be noted as follows.

The single supplier is the subject of natural monopoly, the subjects defined by separate Decrees, Resolutions and Orders of the President of the Republic of Uzbekistan or Resolutions of the Cabinet of Ministers of the Republic of Uzbekistan, as well as the supplier of unique goods (works, services) for public procurement of whichthere are no alternatives in the market.

If it is necessary to purchase goods (works, services) from a single supplier, a direct contract is concluded between him/her and the state customer, which is subject to registration in a special information portal.

The Law establishes that the Accounts Chamber of the Republic of Uzbekistan, the General Prosecutor's Office of the Republic of Uzbekistan,the National Project Management Agency under the President of the Republic of Uzbekistan,as well as the Ministry of Finance of the Republic of Uzbekistan exercise state control. In addition, public procurement is also subject to public control.

In accordance with the Law, in case of non-fulfillment or improper fulfillment of obligations, an entrepreneur is included in the Unified register of unscrupulous performers, and can not participate in public procurement for three years. 
The emerging problems of budget customers with their participation in government procurement and methods of solutions.

1. Many cases of delivery of low-quality and non-certified goods (works, services) by suppliers, as well as the lack of choice of goods with specific parameters on the trading platforms of UZEX, leading to different disagreements between the customer and the supplier after the conclusion of the contract, which leads to an increase in the supply of low-quality goods.

There are two methods for solving problems.

The implementation of the mandatory availability of certificates of conformity for products in the electronic store and auction through the interaction of the Operator and Uzstandart databases.

Second, the creation and implementation of a single national classifier of goods (works, services) for public procurement in conjunction with the State Statistics Committee, Uzstandart, State Customs Committee, UZEX and other interested ministries and departments

2. In the electronic store there is a limited opportunity for customers to obtain reliable information about the product.

The authorized body together with the operator (UZEX) should create conditions for customers to become familiar with the full characteristics of the goods during the two-day trading in the electronic store. When creating this information, the customer will be able to purchase the desired product.

3. When making purchases in the electronic store there is no possibility of grouping goods

The authorized body together with the operator (UZEX) should create the chance to group goods of the same type when making purchases in an electronic store, resulting in convenience for customers and government procurement entities, reducing their time for procurement.

1. To reduce the number of unscrupulous suppliers participating in government procurement, it is recommended to apply the following methods;

First, integration of the portal with the information system of the tax authorities in order to obtain information about the debts of suppliers of goods (works, services) to the budget (taxes and fees);

Second, in order to prevent "one-day firms" from participating in the public procurement process, it is necessary to integrate the portal with the information system of public service centers with business entities according to the "One Window" principle;

Third, the creation in the portal of a database on the activities of suppliers of goods (works, services) (information on previously sold products, debts to the budget (taxes and fees), obligations to other budget organizations, etc.);

Fourth, the creation in the portal of the module for posting reviews and evaluations of the fulfillment of contractual obligations by customers and suppliers of goods (works, services).

As practice shows, the consideration of complaints by the Commission is carried out unilaterally, i.e. only upon receipt of a complaint from the contractor (supplier of goods (works, services. The Law "On Public Procurement" does not provide for submission of a complaint by a state customer, it is necessary to make appropriate changes. As a result, when examining cases in courts, budget organizations lose time from one to 3 months.

2. Nowadays, there is a complex system of payment of advance payments made by the customer and the participant of the procurement procedures (the operator's fee and the deposit of participants, parties). How to simplify?

The authorized body should consider this issue in detail and should make appropriate changes to the regulatory legal acts. This method can simplify the system of payment of advance payments by making payments before or after drawing up a transaction per month (per year) once and then returning it at the request of the customer. As a result, the efficiency of procurement will increase significantly and treasury operations will be quantitatively reduced (up to two days).

The Complaints Commission must work with the authorized body to introduce a system of electronic filing of complaints and electronic complaints, which will create convenience for subjects of public procurement and reduce the time for procurement by customers.

To increase the number of suppliers (manufacturers) to participate in electronic trading:

Firstly, by introducing new methods and methods of public procurement using the concept of a guarantee supplier.

Secondly, by introducing rules that provide for mandatory participation in government procurement of business entities, during their state registration, with tax and levies privileges and conducting their activities in free economic zones. 
Thirdly, the creation of benefits and preferences for business entities, with participation in electronic bidding on public procurement (a simplified mechanism for making deposits, etc.);

Fourthly, raising awareness of business entities about the opportunities and benefits of selling goods (works, services) in the information portal through media coverage.

\section{REFERENCES}

1. Law of the Republic of Uzbekistan of April 9, 2019 "On public procurement" No. ZRU-472.

2. Decree of the President of the Republic of Uzbekistan on September 27, 2018 "On Measures for Implementing the Law of the Republic of Uzbekistan "On Public Procurement"” No. PD-3953

3. On the approval of the regulation on specialized organizations that have the right to provide services for the conduct of public procurement. Registered by the Ministry of Justice of the Republic of Uzbekistan on August 20, 2018. Registration No. 3057.

4. On approval of the regulation on the organization and conduct of procurement procedures. Registered by the Ministry of Justice of the Republic of Uzbekistan on May 26, 2018. Registration No. 3016.

5. Andreas H. Glas, Markus Schaupp, Michael Essig, (2017) "An organizational perspective on the implementation of strategic goals in public procurement", Journal of Public Procurement, Vol. 17 Issue: 4, pp.572-605, https://doi.org/10.1108/JOPP-17-04-2017-B004

6. Thai, K. V. (2001). Public procurement re-examined. Journal of public procurement, 1(1), 9-50. 